\title{
The Silvicultural Significance of Geographic Variation in the White Engelmann Spruce Complex in British Columbia
}

\author{
BY LAURENCE ROCHE \\ Canadian Forestry Service \\ P.O. Box 3800 \\ Ste. Foy, P.O. \\ ODC 165.52:2 (711) \\ "The dormancy curve is very sensitive in distinguishing \\ between spruce provenances and is, therefore, an im- \\ portant parameter in determining the suitability of a part- \\ icular provenance for propagation in a coastal nursery and \\ outplanting in a given region".
}

\begin{abstract}
One hundred and sixty-two spruce provenances, representing allopatric and sympatric populations of white, Engelmann, and Sitka spruce in British Columbia were sown in a coastal nursery. Twelve of these provenances were randomized in four replications, two of which were of regular nursery soil and two of an artificial soil mix. One hundred and fifty were randomized in six replications, all of which were of the artificial soil mix. In the second nursery year a plastic greenhouse was placed over two replications of the 12 provenances.

An assessment of the growth behavior of all provenances showed a strong correlation between time of entering dormancy and geographic origin. A high correlation between time of entering dormancy and total growth is also demonstrated. The dormancy curve is shown to characterize a provenance with some accuracy.
\end{abstract}

High-elevation provenances, which were the first to enter dormancy, were stunted in growth and exhibited a "rosette" appearance as a result of decreased internode length, while certain lowelevation provenances from the interior of British Columbia grew as well as Sitka spruce.

On the basis of these results, recommendations are made in regard to the propagation of interior spruce in coastal nurseries, both in the open and in plastic greenhouses, and in regard to the displacement of spruce provenances in the interior of British Columbia. It is emphasized that these recommendations are tentative and will be modified as information accumulates concerning the genecology of white and Engelmann spruce in British Columbia. A major source of new information in this respect will be the long-term field trials that followed the study reported here. 
De la portée, pour le sylviculteur, de la variation géographique des Epinettes blanches et d'Engelmann, à l'intérieur de leurs zones naturelles, en Colombie britannique

\section{Résumé}

Cent soixante-deux "lots" de graines d'épinette blanche d'Engelmann et de Sitka provenant de lieux différents dans la Colombie-Britannique ont été semés dans une pépinière côtière. Douze d'entre eux furent semés dans 4 lopins choisis au hasard, dont deux en sol ordinaire de pépinière et deux en sol composé artificiellement. Les cent cinquante autres lots furent semés dans 6 lopins choisis au hasard, tous six en sol artificiel. Au cours de la seconde année en pépinière, une serre de plastique fut placée sur deux lopins de douze premiers lots.

Une étude du comportement végétatif de tous les lots a montré une forte corrélation entre le moment de l'entrée en hibernation et l'altitude. Une forte corrélation entre ce même temps d'entrée en hibernation et la hauteur totale fut également observée.

Les lots provenant de haute altitude, qui furent les premiers à entrer en hibernation, étaient en "rosette", vu la longueur moindre de l'entre-noeud; tandis que certains lots de basse altitude de l'intérieur de la Colombie-Britannique ont crû aussi bien que l'épinette de Sitka.

$A$ la suite de ces résultats, des recommandations sont faites en ce qui concerne la multiplication de l'épinette originaire de l'intérieur dans une pépinière côtière, aussi bien en serre de plastique qu'à l'extérieur ainsi qu'en ce qui concerne le déplace- ment des lots d'épinette dans l'intérieur de la Colombie-Britannique.

L'auteur insiste sur le fait que ces recommandations sont préliminaires et seront modifiées au fur et à mesure que les information s'accumuleront concernant la génécologie des épinettes blanches et d'Engelmann en Colombie-Britannique. A ce propos, les essais à long terme sur le terrain, qui suivront l'étude rapportée ici, constitueront une source importante de nouvelles informations.

\section{Introduction}

In recent years there has been considerable expansion in the reforestation activities of the British Columbia Forest Service. Nursery facilities have been greatly increased to allow the production of 75 million seedlings annually by 1975 . Furthermore, tree-breeding work, previously confined to coastal species, has been extended to interior species, particularly white and Engelmann spruce.

The need for more detailed information concerning geographic variation in the spruce complex of the interior of British Columbia was recognized at an early stage in these developments, and in 1962 a program of spruce provenance research was initiated.

During a period of 4 years, studies of geographic variation in seedling populations showed very large differences in growth behavior between provenances. Large differences in cone-scale morphology were also observed, and introgressive hybridization was demonstrated (Roche 1965, 1966). A detailed account of the genecological and taxonomic implications of these investigations is given elsewhere (Roche 1968, 1969a, 1969b). This article, therefore,

Fig. 1. The geographic location of 12 spruce provenances listed in Table 2.

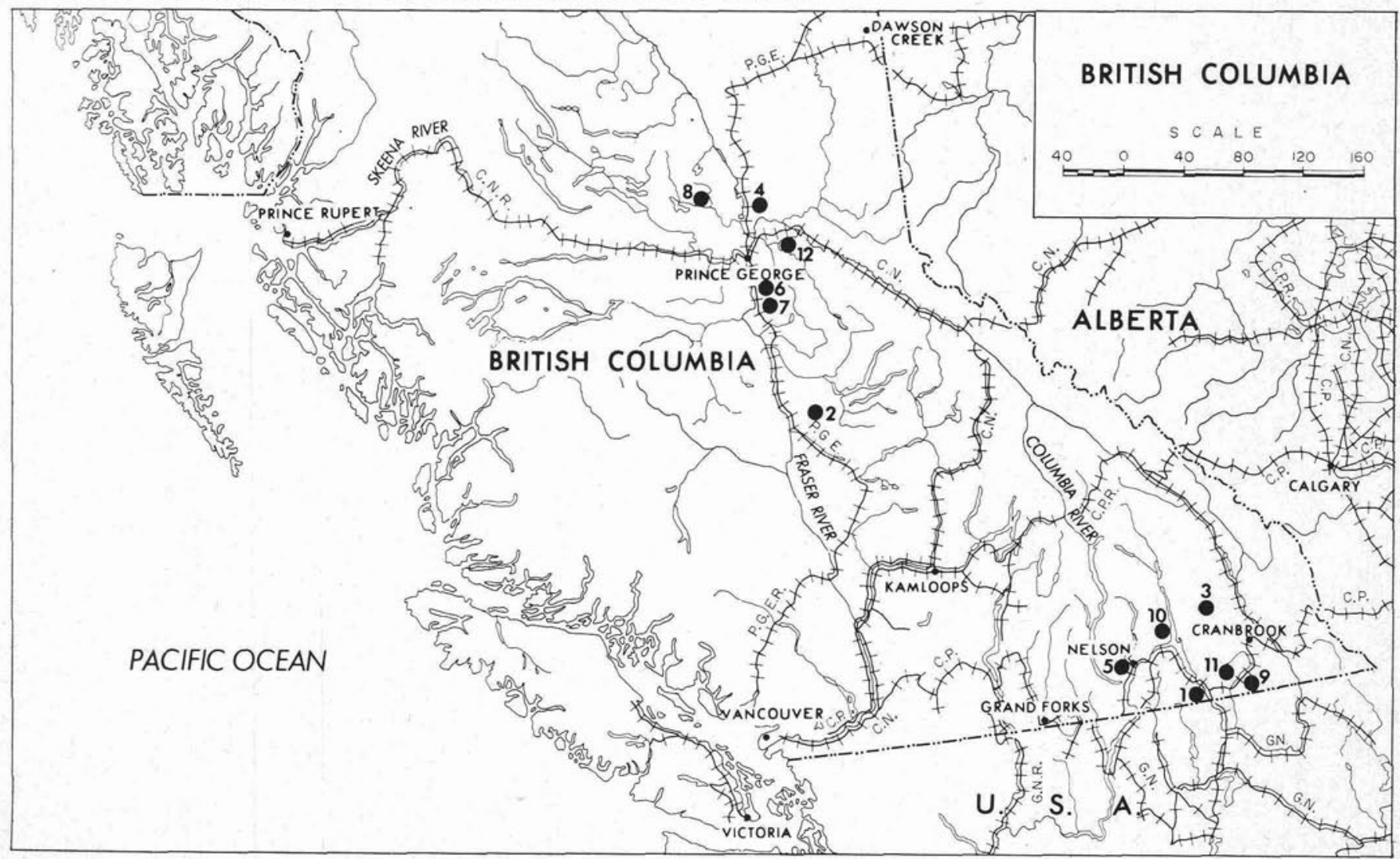


TABLE 1. - Geographic Origin in order of increasing elevation of 150 Spruce Provenances Sown in the Cowichan Nursery, and per cent Dormant on six Different Dates During the Second Nursery

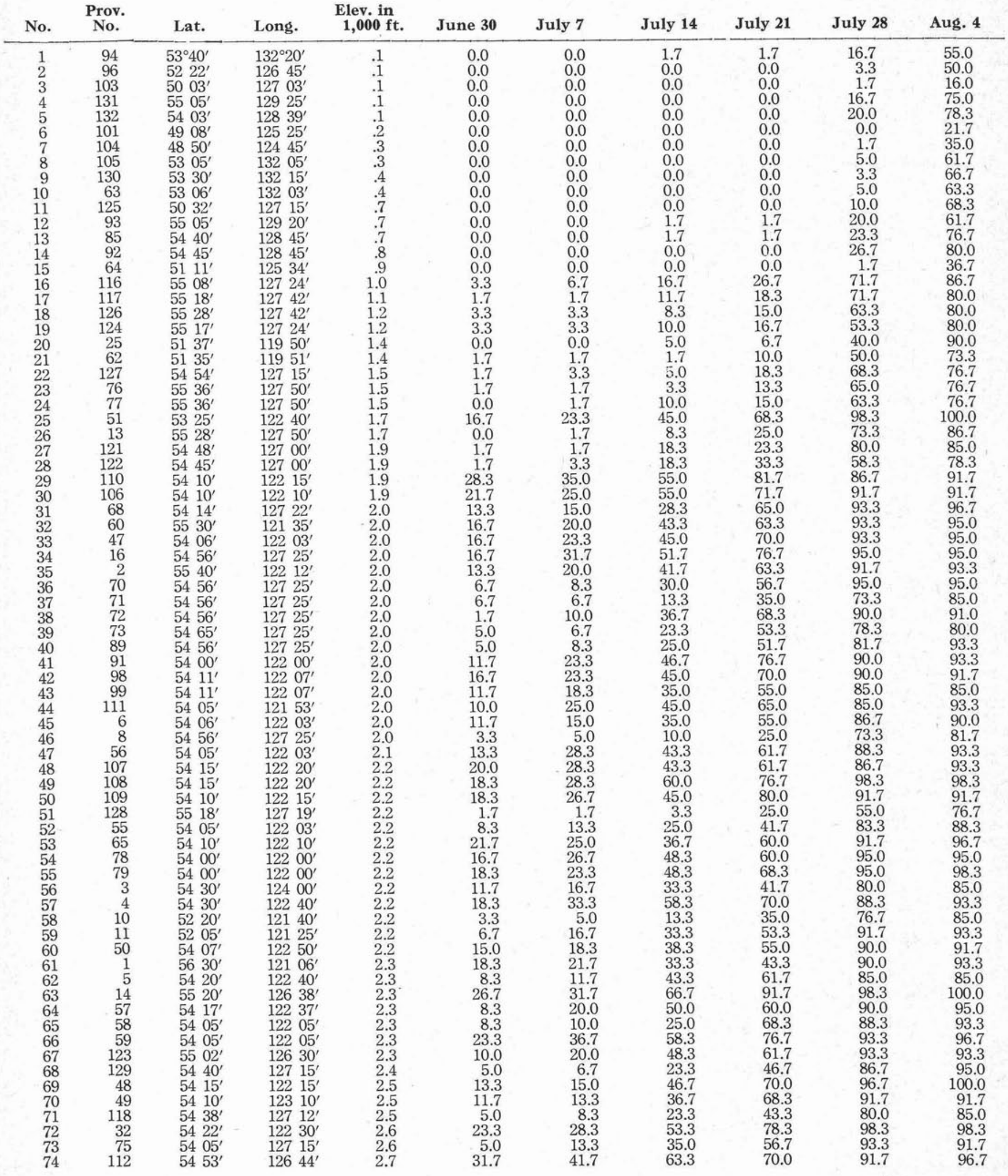




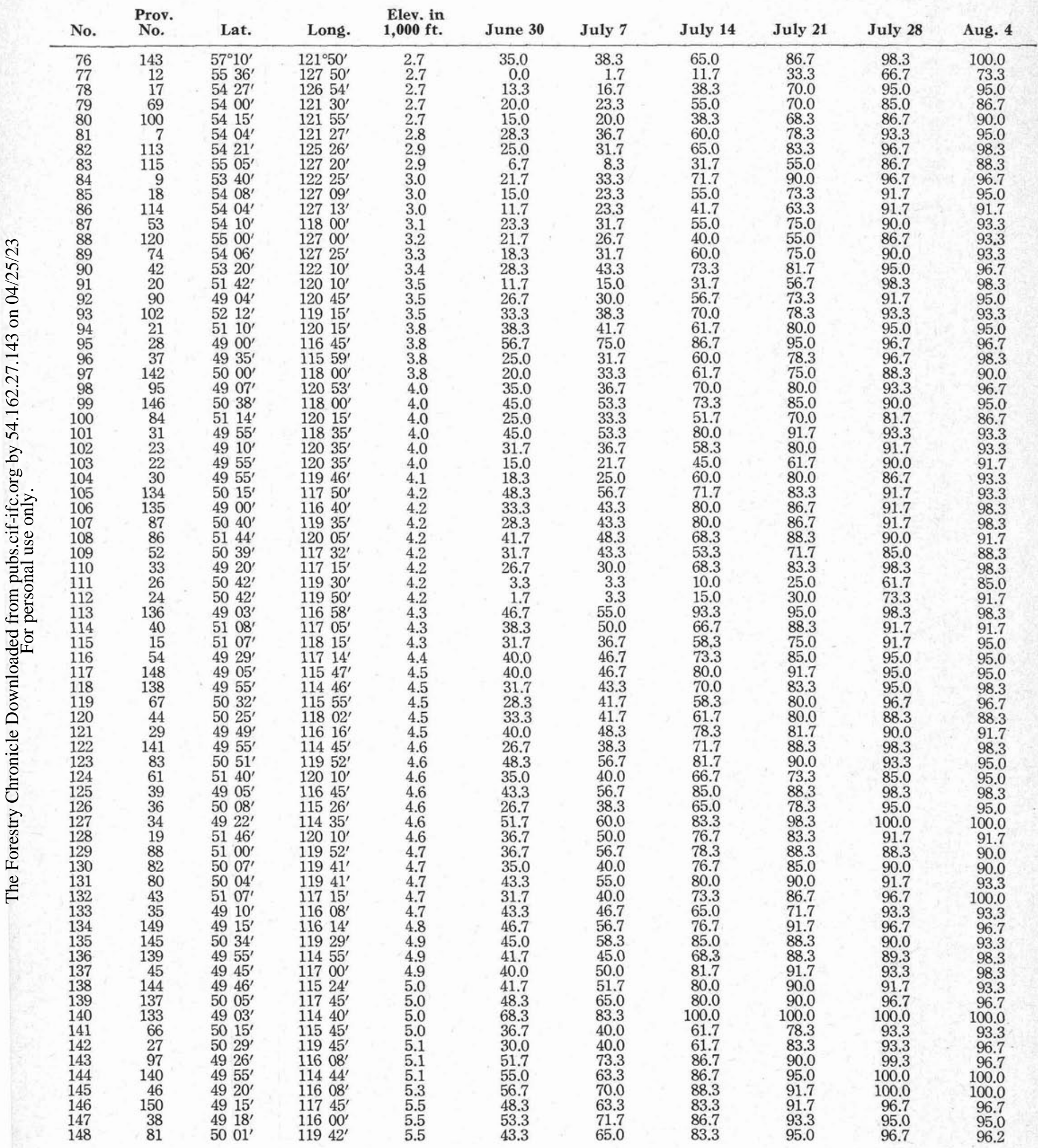


is concerned primarily with the bearing of the results on the silviculture of the species in British Columbia.

\section{Materials and Methods}

Twelve white and Engelmann spruce provenances were sown in the spring of 1964, and 150 white, Engelmann and Sitka provenances were sown in the spring of 1965 at the British Columbia Forest Service coastal nursery, at Cowichan Lake. The geographic origin of the 150 provenances, which represent allopatric and sympatric populations of white. Engelmann and Sitka spruce, is given in Table 1. Table 2 and Fig. 1 give the geographic origin of the 12 provenances.

The 12 provenances sown in the spring of 1964 were randomized in each of four blocks and sown 6 inches apart at right angles to the long axis of the bed. Two beds were made with California B2 soil mix (Baker, 1957), and two with a local soil.

In the fall of 1964, the 12 provenances were sampled by placing a board with 10 evenly spaced teeth alongside each row of seedlings and taking the seedling that was closest to each of the 10 teeth to give 10 seedlings per row. Since there were four replications, each provenance was represented by 40 seedlings. Shoot length (SL) and root collar diameter (RCD) were obtained for every seedling, and the mean of these measurements was calculated for the 12 provenances.

During the early spring of the second year a plastic greenhouse was placed over two blocks, one of the California mix, and the other of the local soil. Flushing and dormancy were assessed, and shoot extension was measured every two weeks during the growing season. It was possible, therefore, to construct a growth curve for each of the 12 provenances.

The 150 provenances sown in the spring of 1965 were randomized in each of six blocks and sown at right angles to the long axis of the beds, all of which were prepared with the California mix. In the fail of 1966 a sample of 60 seedlings of each of the 150 provenances was harvested. The seedlings were cut at the root collar, and the following measurements obtained in the laboratory: shoot length (SLI), root collar diameter (RCD1), and dry weight (DW1).

A dormancy assessment was made of the 150 provenances by scoring permanently marked seedlings in each row. In all instances a seedling was considered dormant when the terminal needles of

TABLE 2. - Geographic Origin of 12 Spruce Provenances Sown in the Cowichan Lake Nursery

\begin{tabular}{cccc} 
Number & Latitude & Longitude & Elevation (ft.) \\
\hline 12 & $54^{\circ} 06^{\prime}$ & $122^{\circ} 03^{\prime}$ & 2,100 \\
2 & $52^{\circ} 20^{\prime}$ & $121^{\circ} 40^{\prime}$ & 2,200 \\
8 & $54^{\circ} 30^{\prime}$ & $122^{\circ} 40^{\prime}$ & 2,300 \\
4 & $54^{\circ} 22^{\prime}$ & $122^{\circ} 30^{\prime}$ & 2,600 \\
6 & $53^{\circ} 40^{\prime}$ & $122^{\circ} 25^{\prime}$ & 3,000 \\
7 & $53^{\circ} 20^{\prime}$ & $122^{\circ} 10^{\prime}$ & 3,400 \\
1 & $49^{\circ} 00^{\prime}$ & $116^{\circ} 45^{\prime}$ & 3,900 \\
3 & $49^{\circ} 49^{\prime}$ & $116^{\circ} 16^{\prime}$ & 4,500 \\
9 & $49^{\circ} 14^{\prime}$ & $115^{\circ} 58^{\prime}$ & 4,700 \\
10 & $49^{\circ} 45^{\prime}$ & $117^{\circ} 00^{\prime}$ & 4,900 \\
11 & $49^{\circ} 20^{\prime}$ & $116^{\circ} 08^{\prime}$ & 5,300 \\
5 & $49^{\circ} 35^{\prime}$ & $117^{\circ} 48^{\prime}$ & 5,700
\end{tabular}

the epicotyl were stiff and whorled and a terminal bud was visible. At the end of the second growing season the permanently marked seedlings were harvested by cutting at the root collar, and the following measurements obtained in the laboratory: shoot length (SL2), root collar diameter (RCD2) and dry weight (DW2). All measurements made on the 150 provenances are given in Table 3 .

TABLE 3. - Measurements of Growth Made on 150 Spruce Provenances, and Measurements of Factors of the Environment at Their Place of Origin

Measurements

Code

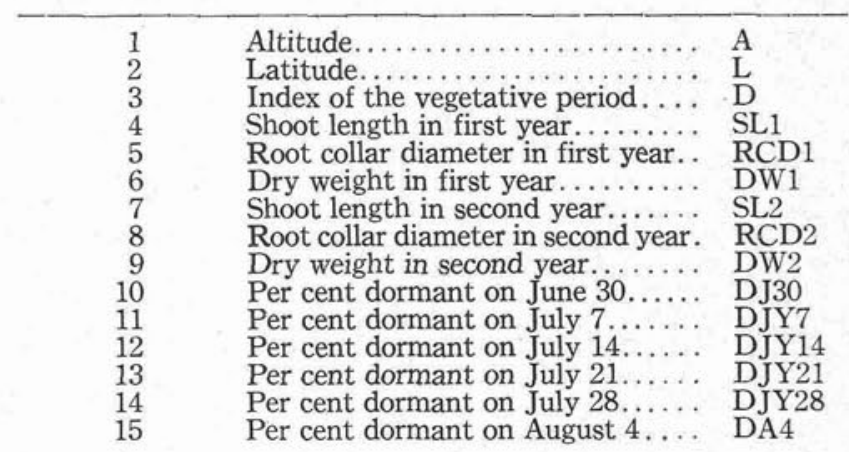

\section{Results}

The first year's growth behavior of the 12 provenances sown in the spring of 1964 in the Cowichan nursery was significantly different at the 0.01 level of probability. On the prepared soil the 12 provenances, segregated according to growth response, formed two intergrading groups. Group 1 comprised high-elevation provenances from southern latitudes, and group 2 low-elevation provenances from northern latitudes (Fig. 2).

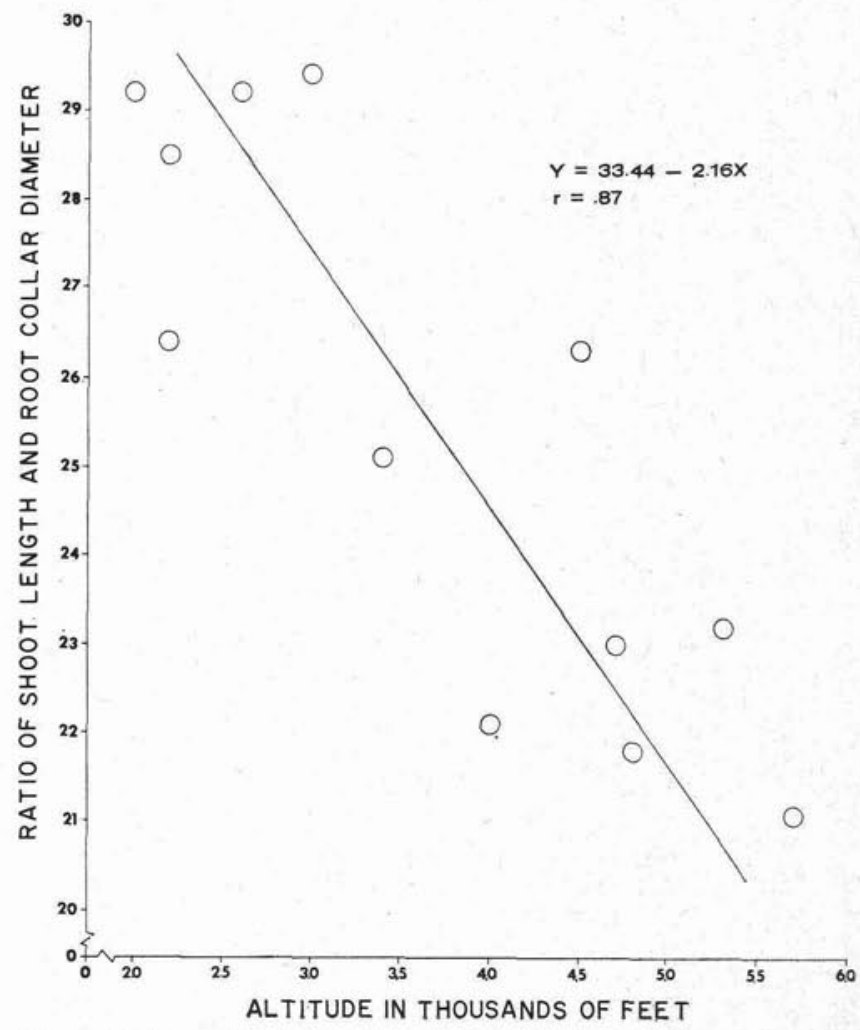

Fig. 2. Relation between altitude and growth of 12 one-year-old spruce provenances on soil mix. Each point on the curve is the mean of 20 seedlings. 
Growth during the second year of the California mix and on the local soil, both inside and outside the plastic greenhouse, is illustrated in Fig. 3. It will be seen that during the second year's growth maximum differences between the 12 provenances occurred in the plastic greenhouse on the local soil (Fig. 3 and 4 ).

The differences between shoot length of high- and low-elevation provenances on regular nursery soil inside the greenhouse are attributable, not to the time of flushing, but to the time of growth cessation and the initiation of dormancy. On regular nursery soil inside the greenhouse all 12 provenances flushed at approximately the same time but entered dormancy at different times. For example, provenance 5 (elev. 5,700 ft.) was dormant by May 25, but provenance 8 (elev. 2,300 ft.) did not become dormant until August 13.

All growth measurements made on the 150 provenances, except root collar diameter in the first year, are highly correlated with factors of the environment at the place of origin of the provenances as expressed by altitude, latitude, and the number of days in the vegetative period. Root collar diameter in the first year is not correlated with altitude or the vegetative period (Table 4).

The per cent dormant on June 30, July 7, 14, 21 and 28 , and August 4 is highly correlated with altitude and the vegetative period. The highest correlation between any one measurement of growth behavior of the 150 provenances and factors of the environment is that between per cent dormant on July 14 and altitude. The correlation coefficient for dry weight and per cent dormant on July 28 is -0.80 (Table 4).

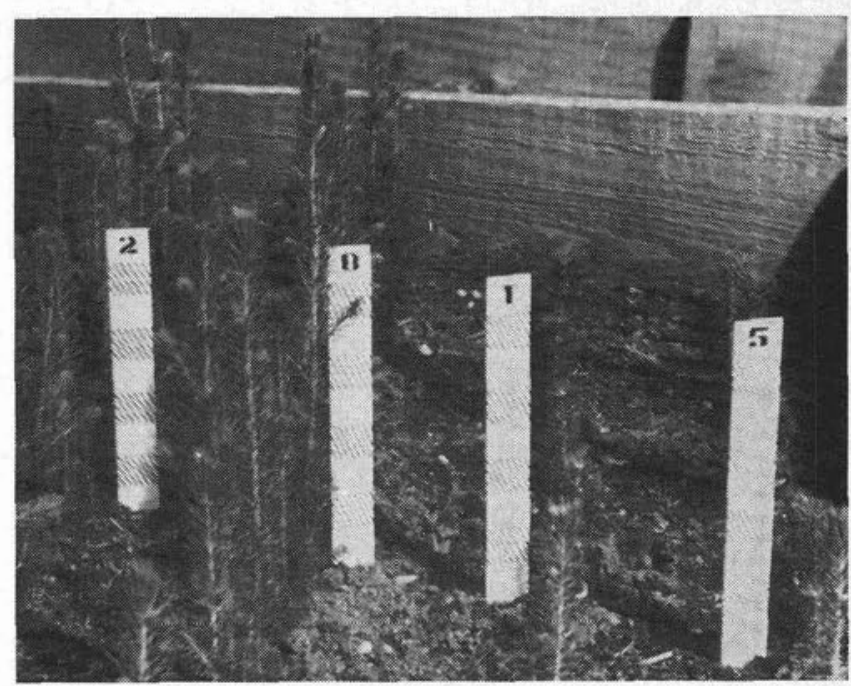

Fig. 4. The differential growth behavior of two-year-old spruce provenance from different elevations in British Columbia when grown in a plastic greenhouse on regular nursery soil. The scale on each marker is in inches. See Fig. 1 and Table 2 for geographic origin of each provenance.

There is a period during the growing season when differences between provenances in time of entering dormancy is at a maximum. To determine this period it is necessary to construct a dormancy curve. The dormancy curve is very sensitive in distinguishing between provenances (Fig. 5, Table 1).

There is a high correlation between date of entering dormancy and total growth of seedlings. The seedlings that were the first to enter dormancy had the lowest dry weight. The correlation coefficient for dry weight and per cent dormant on July 28 is -0.80 (Table 4).

TABLE 4. - Relationships Between Growth and Dormancy During First and Second Year and Factors of the Environment for 150 Spruce Provenances Grown in a Coastal Nursery

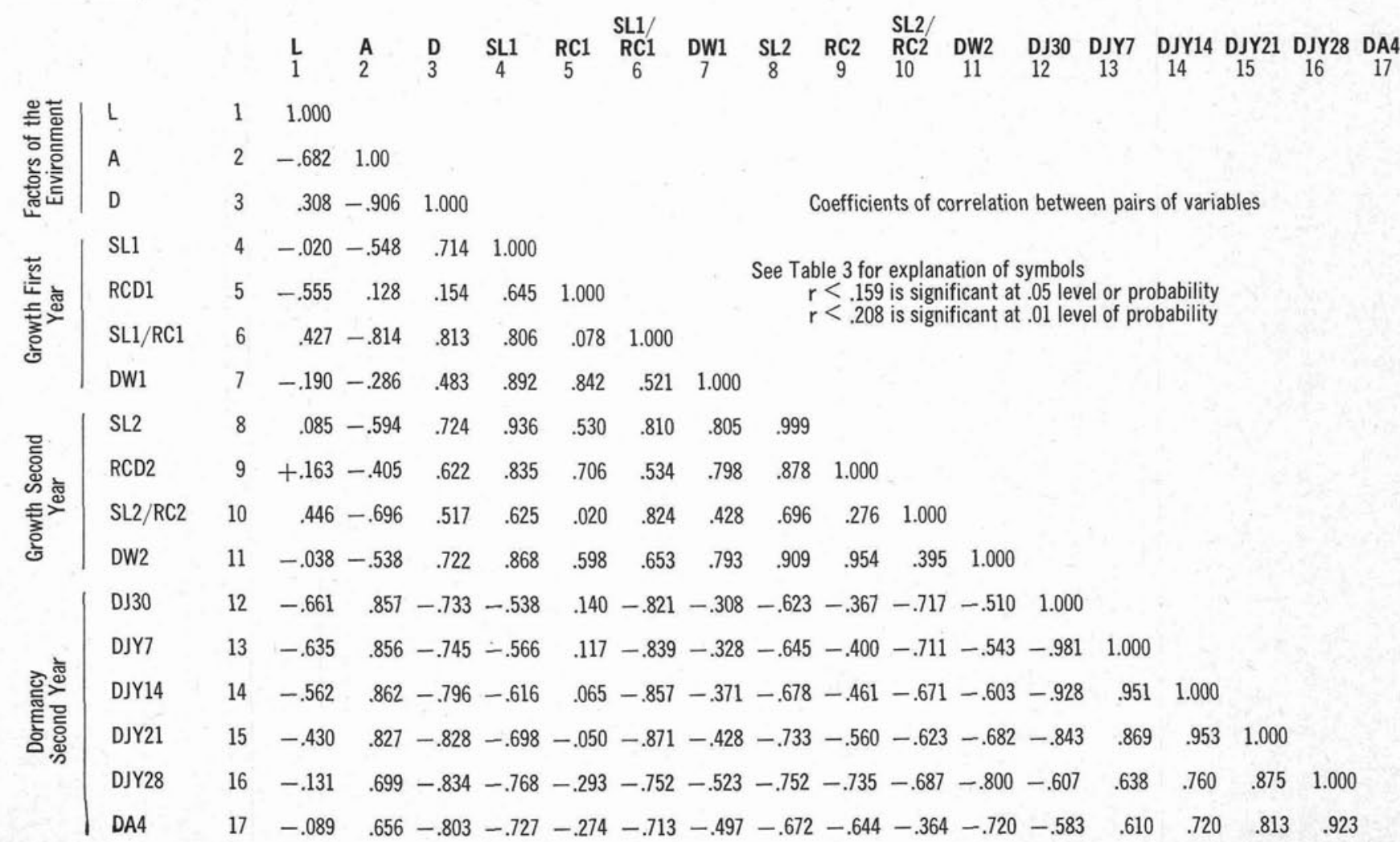


Fig. 3. Second year's growth of 12 spruce provenances, six from below $3,500 \mathrm{ft}$. and six from above: 1 and 5 , soil mix inside the plastic greenhouse; 2 and 6 , regular nursery soil inside the greenhouse; 3 and 7 , soil mix outside the greenhouse; 4 and 8 , regular nursery soil outside the greenhouse. Shoot length is given in centimeters.

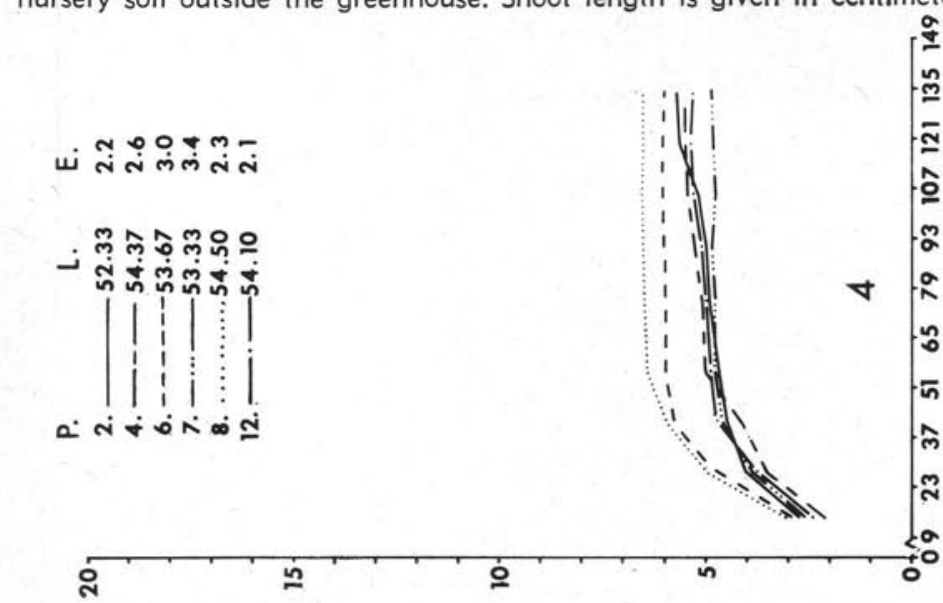

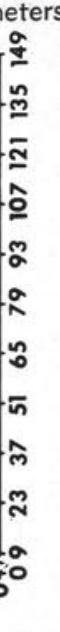

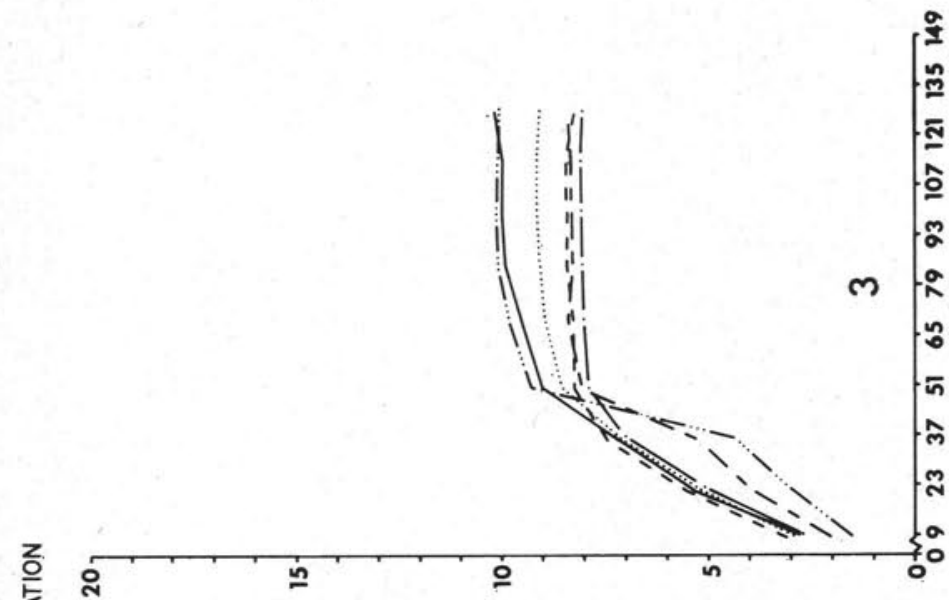

㟧
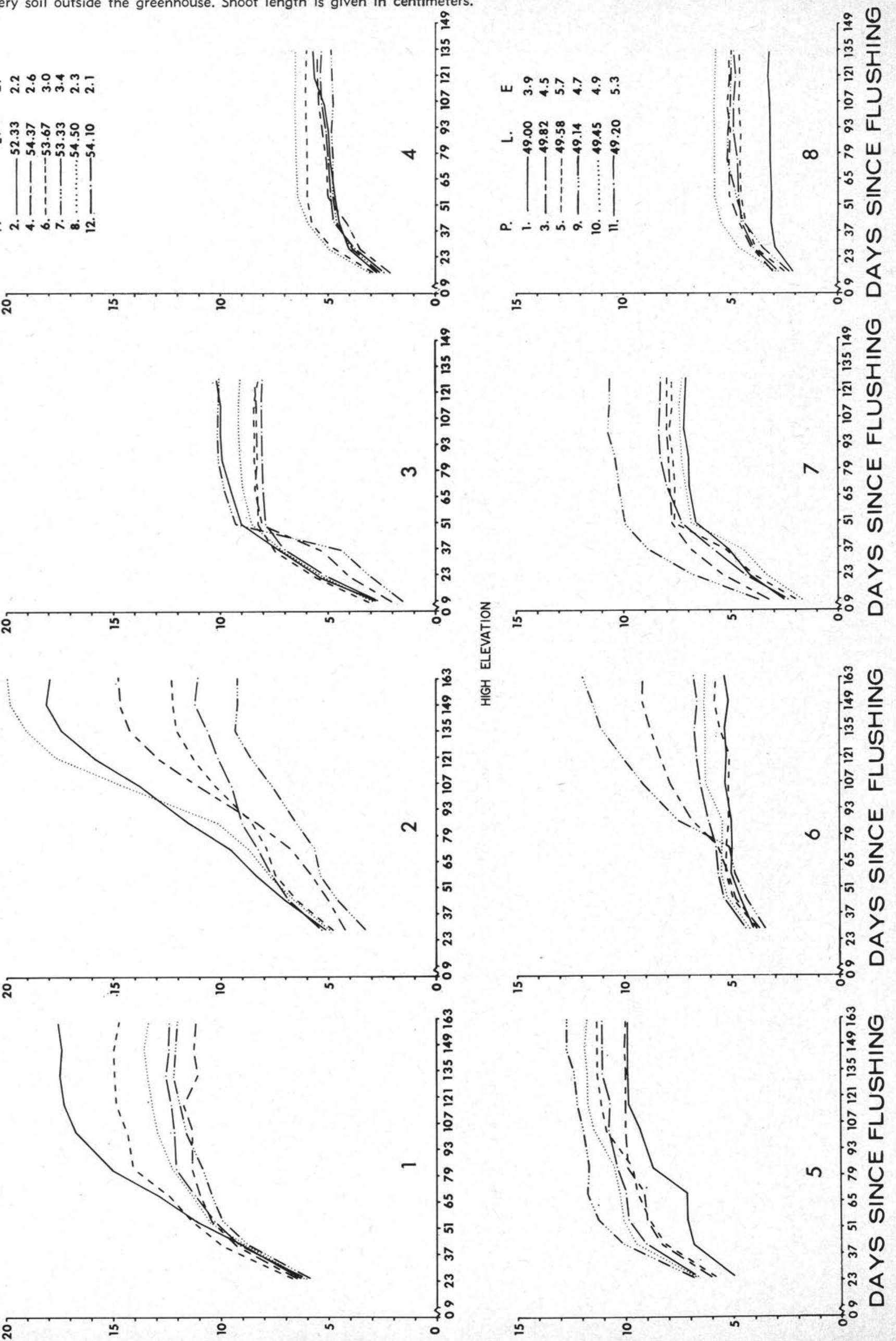

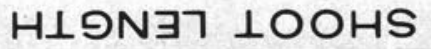




\section{Discussion}

Evidence presented elsewhere indicates that the differential growth in spruce provenances from the white-Engelmann spruce complex in the Cowichan Lake nursery is conditioned by photothermal adaptation, and that it is the time of growth cessation and dormancy, and not the time of flushing, which determines the adaptability of a given provenance in a given area (Roche 1969b). It has also been
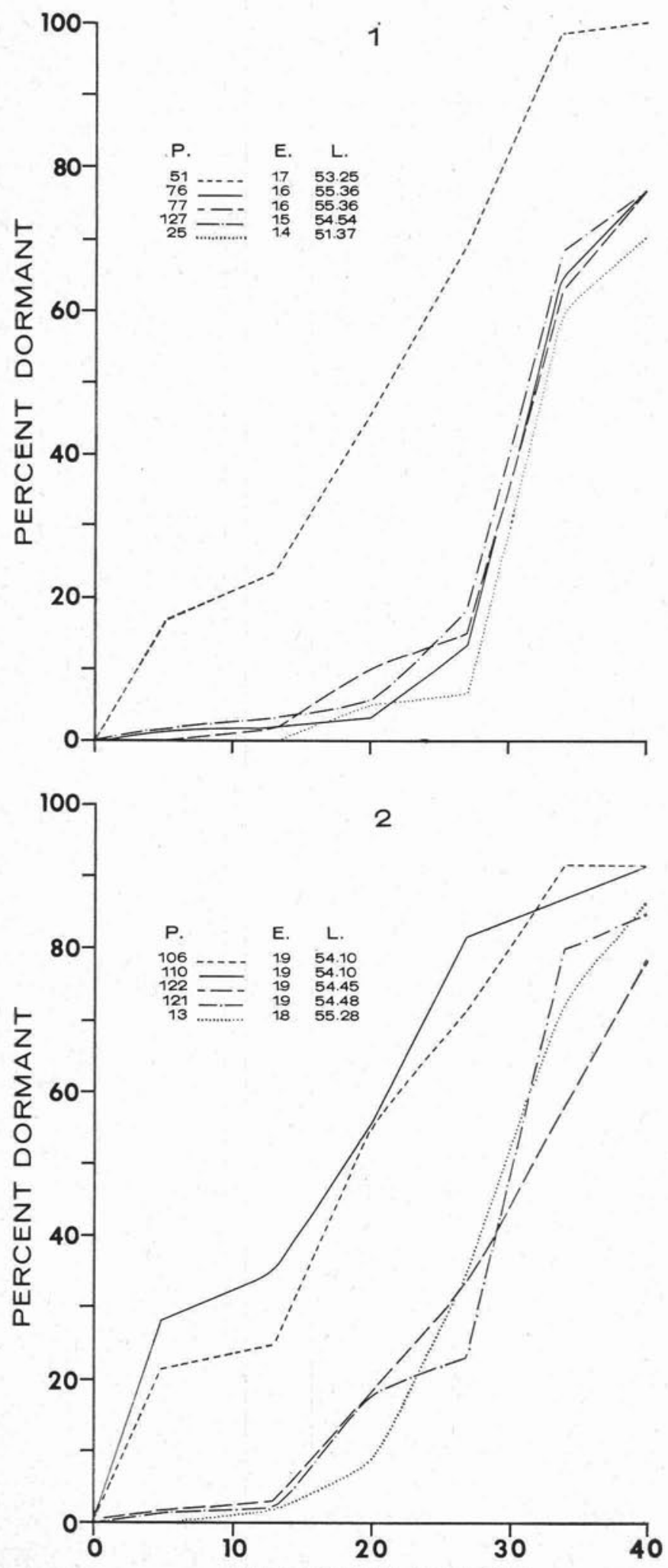

DAYSFROMJUNE 25 shown that the variation pattern in spruce populations from northwestern British Columbia, in the region of the Nass and Skeena river drainages, is influenced by the penetration of Sitka spruce populations into populations of white spruce (Roche 1969a).

The high-elevation provenances entered dormancy during the 1966 growing season at Cowichan Lake when temperatures were increasing but when the photoperiod had begun to decrease. Low-elevation provenances also entered dormancy when temperature was increasing but at a much later date than high-elevation provenances. For example, the Clearwater provenance (No. 124, lat. $51^{\circ} 40^{\prime}$, long. $120^{\circ} 10^{\prime}$, elev. $4,600 \mathrm{ft}$.) showed 35 per cent dormant on June 30 , when the Birch Island provenance, from approximately the same latitude and longitude but different elevation (No. 20, lat. $51^{\circ} 37^{\prime}$, long. $119^{\circ} 50^{\prime}$, elev. $1,400 \mathrm{ft}$.), showed no sign of dormancy, and the latter showed only 5 per cent dormant on July 14, when the Clearwater provenance was 66 per cent dormant (Table 1).

Similarly, provenance 42 , from the Prince George region (No. 90 , lat. $53^{\circ} 20^{\prime}$, long. $122^{\circ} 10^{\prime}$, elev. 3,400 ft.), showed 28 per cent dormant on June 30 , while provenance 10, from Soda Creek (No. 58, lat. $52^{\circ} 20^{\prime}$, long. $121^{\circ} 40^{\prime}$, elev. $2,200 \mathrm{ft}$.), showed only 3 per cent dormant on that date (Table 1).

These examples are typical of the general pattern of growth cessation and the initiation of dormancy in all populations from the white-Engelmann spruce complex growing at Cowichan Lake. The pattern varies, however, in populations from the general region of the Nass and Skeena rivers in northwestern British Columbia. It seems clear that the intrusion of Sitka spruce genes, as a result of decreasing continentality, influences the pattern of variation in these populations.

For example, it will be seen that provenance 128 , from the region of Hazelton in northwestern British Columbia (No. 51, lat. 55 $18^{\prime}$, long. $127^{\circ} 19^{\prime}$, elev. 2,200 ft.), and provenance 14, from Babine Lake (No. 63, lat. $55^{\circ} 20^{\prime}$, long. $126^{\circ} 38^{\prime}$, elev. $2,300 \mathrm{ft}$.), differ significantly only in regard to longitude. Yet there is a considerable difference in time of entering dormancy. On June 30 the Hazelton provenance showed only 2 per cent dormant while the Babine Lake provenance showed 27 per cent dormant (Table 1).

In regard to time of entering dormancy, the Hazelton provenance is typical of all the provenances

Fig. 5. Dormancy curves for provenances from sympatric populations of white and Sitka spruce, and low-elevation spruce provenances from the white-Engelman complex. In section 1 of the figure, provenance 51 is from Hixon, south of Prince George in central British Columbia. Provenances 76, 77 and 127 are from northwest British Columbia, in the region of the Kispiox river. Provenance 25 is from Birch Island in south central British Columbia. This provenance is from the lowest elevation of all interior provenances (1,400 ft.). In section 2, provenances 106 and 110 are from northeastern British Columbia, near Giscome. Provenances 13, 121 and 122 are from the Hazelton-Smithers region in northwestern British Columbia. Note the sensitivity of the dormancy curve in distinguishing provenances, and the similarity of the curve of the lowelevation Birch Island provenance to the curves of provenances from northwestern British Columbia. $\mathrm{P}-$ provenance; $\mathrm{E}-$ elevation; L - altitude. 
from the Nass and Skeena river drainages. All these provenances entered dormancy later than provenances from east of the general region (Table 1).

It will be seen from Table 4 that there is a high correlation between time of entering dormancy and total growth. This correlation resulted in differences between provenances in regard to their suitability as planting stock. The low-elevation provenaces from the southern interior of the province, for example the Birch Island provenance already referred to, grew as well as the coastal Sitka spruce provenances in the Cowichan nursery. On the other hand, the high-elevation provenances, which entered dormancy early in the season, were stunted in appearance and considerably smaller than the lowelevation provenances.

There is evidence, therefore, that the propagation of high-elevation spruce provenances in coastal nurseries at southern latitudes, either on Vancouver Island or on the mainland of British Columbia, should be discontinued. Such populations growing in coastal nurseries at southern latitudes enter dormancy early and have a stunted "rosette" appearance resulting from decreased internode length. On the other hand, the same populations are likely to produce seedlings with desirable silvicultural characteristics much more rapidly in a northern nursery such as Telkwa (lat. ca. $55^{\circ} 00^{\prime}$ ), in northwestern British Columbia, approximately 6 degrees north of the coastal nurseries. At this latitude, there is an appreciable gain in photoperiod.

Corroborative evidence for the foregoing observation is available from a study initiated by the author in 1963 at the Telkwa nursery in northwestern British Columbia and at the Duncan nursery on Vancouver Island, which is at approximately the same latitude as the Cowichan Lake nursery and 6 degrees south of the Telkwa nursery. Thirteen provenances of white and Engelmann spruce were sown at both nurseries in the spring of 1963. Table 5 shows the percentage of seedlings at both nurseries which had entered dormancy by August 22 during the second growing season (Roche, 1964). It will be seen that a greater percentage of seedlings of all provenances at the Duncan nursery had entered dormancy at the date given.

TABLE[5. Percentage of 2-year-old Seedlings of 13 Provenances Dormant by August 22 at a Southern and a Northern Nursery in British Columbia

\section{Per Cent}

Dormant Duncan Telkwa

Number Latitude Longitude Ca. lat. Ca. lat.

\begin{tabular}{cccccc} 
Number & \multicolumn{2}{c}{ Latitude Longitude } & (ft.) & $\mathbf{4 9}^{\circ} \mathbf{0 0 ^ { \prime }}$ & $\mathbf{5 5}^{\circ} \mathbf{0 0}$ \\
\hline 8 & $51^{\circ} 40^{\prime}$ & $119^{\circ} 30^{\prime}$ & 1,400 & 1 & 0 \\
6 & $53^{\circ} 25^{\prime}$ & $111^{\circ} 40^{\prime}$ & 1,800 & 22 & 11 \\
4 & $54^{\circ} 10^{\prime}$ & $122^{\circ} 30^{\prime}$ & 2,000 & 37 & 17 \\
3 & $54^{\circ} 20^{\prime}$ & $122^{\circ} 10^{\prime}$ & 2,000 & 54 & 16 \\
2 & $55^{\circ} 40^{\prime}$ & $122^{\circ} 12^{\prime}$ & 2,000 & 52 & 15 \\
7 & $52^{\circ} 30^{\prime}$ & $122^{\circ} 00^{\prime}$ & 2,200 & 34 & 12 \\
5 & $54^{\circ} 07^{\prime}$ & $122^{\circ} 50^{\prime}$ & 2,300 & 42 & 18 \\
1 & $56^{\circ} 00^{\prime}$ & $121^{\circ} 06^{\prime}$ & 2,300 & 69 & 23 \\
11 & $50^{\circ} 15^{\prime}$ & $118^{\circ} 00^{\prime}$ & 3,200 & 39 & 9 \\
9 & $51^{\circ} 5^{\prime}$ & $120^{\circ} 30^{\prime}$ & 3,800 & 69 & 36 \\
10 & $50^{\circ} 40^{\prime}$ & $118^{\circ} 00^{\prime}$ & 4,000 & 55 & 18 \\
12 & $49^{\circ} 30^{\prime}$ & $117^{\circ} 00^{\prime}$ & 4,700 & 33 & 18 \\
13 & $49^{\circ} 15^{\prime}$ & $116^{\circ} 00^{\prime}$ & 4,700 & 63 & 23 \\
\hline
\end{tabular}

Note that the 7-degree latitudinal range confounds the altitudinal effect in regard to time of entering dormancy.

\section{Conclusions}

High-elevation provenances cannot benefit from a long growing season but can avail of increased day length. This is a major conclusion deduced from the performance of the provenances at Cowichan, and it should be taken into consideration in all plans relating to the displacement and propagation of interior spruce provenances, whether in nurseries or in plantations.

The dormancy curve is very sensitive in distinguishing between spruce provenances and is, therefore, an important parameter in determining the suitability of a particular provenance for propagation in a coastal nursery and outplanting in a given region. In this regard Table 1 is of some value in that the expected dormancy curve of a given provenance in a coastal nursery at latitude $49^{\circ} 00^{\circ}$ may be read from the table if the provenance is from within the region studied.

All high-elevation provenances at the Cowichan nursery entered dormancy when temperatures were increasing and the photoperiod was decreasing. Therefore, no silvicultural gain is obtained by propagating high-elevation spruce provenances in coastal nurseries at southern latitudes in British Columbia. On the contrary, because of the close correlation between shoot extension and time of entering dormancy, such a practice will almost certainly increase the cost of planting stock because of the length of time required to obtain seedlings of suitable size for outplanting. Therefore, since time of entering dormancy is mediated by the prevailing photothermal regime, a northern nursery is preferable for the propagation of high-elevation spruce provenances.

Spruce populations from below 2,000 feet and south of latitude $55^{\circ} 00^{\prime}$ will respond to artificially increased temperatures. Therefore, these provenances can be grown on the coast with optimum silvicultural advantage if temperatures are increased artificially, e.g. by the use of plastic greenhouses. Furthermore, these populations do not require the stimulus of a prepared soil of high fertility but will respond vigorously to increased temperatures while growing on regular nursery soil. High-elevation provenances also respond to increased temperatures but not to the same extent as low-elevation provenances.

All spruce provenances south of latitude $53^{\circ} 00^{\prime}$ and below 2,500 feet may be expected to grow rapidly in coastal nurseries in southern latitudes even without the use of plastic greenhouses. Indeed, some of these provenances, e.g. the Birch Island provenances, will grow as rapidly as Sitka spruce in a coastal nursery. It is clear that these provenances have considerable silvicultural potential, and that they will represent an important component in any tree improvement program for spruce in the interior of British Columbia. For these reasons, a special effort should be made to collect seed from lowelevation spruce populations south of latitude $53^{\circ} 00^{\prime}$. This has been done for the Birch Island provenance, of which ample seed is available for further experimentation. 
Frequently, reforestation projects are scheduled for areas for which no seed of local origin is available, and consequently seed from other regions is required. The present study indicates that a displacement of 1,000 feet upwards will, in most instances, result in a detrimental silvicultural effect. A displacement of 500 feet is also likely to result in a measurable effect. In this regard, survival during the first 1 to 5 years is not a good measure of the ill effects of the environment on a displaced provenance. A displaced provenance, which shows 100 per cent survival during the first few years, could nevertheless be quite ill-adapted to its new environmental. There are several reasons for this. In the first place, the climatic pattern during the first few years may be atypical and not representative of the average environment. Secondly, the outplanting technique in relation to size of stock can have a drastic effect on survival.

Though survival may not be drastically affected by an upward displacement of seed, growth will be affected. Consequently, it is probably unwise silviculturally to displace a provenance more than 500 feet upwards anywhere in British Columbia. No serious detrimental effect may be expected to result from a downward displacement of seed, while a downward and northward displacement will probably result in silvicultural gain.

The question as to how far north southern populations can be displaced without detrimental silvicultural effects can only be determined from the field test. It is likely, however, that (other things being equal, e.g. site index and moisture regime) a displacement of 2 to 3 degrees northward is silviculturally feasible for high-elevation spruce provenances from southern latitudes. On the other hand, it is likely that a transfer north of more than 3 degrees will probably result in a detrimental silvicultural effect in southern provenances from low elevations.

\section{Literature Cited}

BAKER, K. F., 1957. University of California system of producing healthy container plants. Manual 23, Calif. Agr. Exp. Sta., Berkeley. 331 p.

ROCHE, L., 1964. Genetic variation and its assessment in an indigenous coniferous species. Unpublished report, library, B.C. Forest Serv., Victoria.

1965. The growth behaviour of interior spruce in the nursery. B.C. Forest Serv. Res. Rev. p. 19-24

1966. The growth behaviour of interior spruce in the nursery. B.C. Forest Serv. Res. Rev. p. 36-43.
It is clear that the coastal influence penetrates well into the interior of British Columbia, that in the Nass, Skeena and Bulkley river basins there are sympatric populations of white and Sitka spruce, and that in the sympatric zone there is evidence of hybridization between these species.

Assuming that there is hybridization between white and Sitka spruce in the areas mentioned, it is not certain that the hybrid is of silvicultural value. In any event, it is likely that no silvicultural advantage can be gained by moving seed out of this zone into other parts of British Columbia. It is possible, however, that high-elevation southern provenances, or low-elevation northern provenances (to lat. $55^{\circ} 00^{\prime}$ ), can be transferred into this area without serious detrimental effect.

It must be stressed that the foregoing general recommendations concerning the transfer of seed and the propagation of seedlings in the nursery are tentative. These recommendations will be modified as further knowledge is available concerning the genecology of white and Engelmann spruce in British Columbia. A major source of new information in this respect will be the long-term field trials that followed the study reported here.

\section{Acknowledgments}

The assistance given in statistical analysis by $A$. R. Fraser and M. Kovats, Research Division, British Columbia Forest Service, and A. Kozak, Faculty of Forestry, University of British Columbia, is acknowledged. The author also acknowledges the considerable technical assistance and facilities received from many other personnel in the British Columbia Forest Service, and in particular from those in the Research Division under the direction of R. H. Spilsbury. To Miss E. Lemon, librarian, B.C. Forest Service, the author is especially grateful.

1968. The value of short term studies in provenance research. Commonwealth Forest. Rev. 47: 14-26

1969a. Introgressive hybridization in the spruce species of British Columbia. Spruce Symposium, Eleventh Meeting of the Committee on Forest Tree Breeding in Canada, Macdonald College (in press).

1969b. A genecological study of the genus Picea in British Columbia. New Phytol. 65:505-554.

\section{Horton Forestry Services Ltd. SILVICULTURISTS, APPRAISERS KEITH HORTON, R.P.F.,}

R. R. 4, STOUFFVILLE, ONT.

Tel.: 416 - 888-1738 